\title{
Eksplorasi Properti Psikometrik Kuesioner Takwa kepada Allah Ta'ala
}

\author{
Irwan Nuryana Kurniawan ${ }^{1}$ \\ 1,2Universitas Islam Indonesia/Prodi Psikologi; \\ email: *irwannuryanakurniawan@gmail.com
}

\begin{abstract}
Abstrak
Meskipun Takwa kepada Allah Subhanahu wa Ta'ala menjadi salah satu satu indikator utama untuk kesuksesan tujuan pendidikan nasional, evaluasi pembelajaran di semua jenjang pendidikan yang ada di Indonesia hanya menyediakan informasi prestasi akademik saja. Penelitian ini merupakan respon terhadap ketiadan instrument evaluasi pembelajaran afektif dan bertujuan untuk mengekplorasi properti psikometrik dari Kuesioner Takwa kepada Allah (KTA; Fikri \& Kurniawan, 2013; 27 aitem dengan $\square=0.890$ ). Penelitian ini melibatkan 220 orang santri, terdiri atas $57,3 \%$ santri laki-laki dan $42,7 \%$ santri perempuan dan rentang usia mereka antara 15 tahun sampai 27 tahun $(\mathrm{M}=17.77$ tahun, $\mathrm{SD}=1.90)$. Untuk keperluan validasi Kuesioner Taqwa kepada Allah, kepada mereka juga diberikan Surrender to God Scale (SGS; Wong-McDonald \& Gorsuch, 2000), Flourishing Scale (FS; Diener, Wirtz, Tov, Kim-Prieto, Choi, Oishi, \& Biswas-Diener, 2009), dan Negative Affect Subscale (NA Subscale of SPANE; Diener, Wirtz, Tov, Kim-Prieto, Choi, Oishi, \& Biswas-Diener, 2009) sebagai variabel kriteria, dan Reynolds Short-Form of Marlowe-CrowneSocial Desirability Scale (Reynolds Short Form of MCSDS; Reynolds \& Gerbasi, 1982) sebagai variabel kontrol. Hasil analisis mendemonstrasikan Kuesioner Tawakal kepada Allah memiliki bukti psikometrik awal (validitas konstrak, konkuren, konvergen, divergen, dan reliabilitas) yang memuaskan sebagai instrument evaluasi pembelajaran. Temuan, implikasi, dan limitasi penelitian didiskusikan secara singkat.
\end{abstract}

Kata kunci: Kuesioner Takwa kepada Allah Ta’ala, Properti Psikometrik

\section{Exploring the Psychometric Properties of the Takwa Toward Allah Wa Ta'ala Questionnaire}

\begin{abstract}
Although Takwa kepada Allah Subahanahu wa Ta'ala became one of the main indicators for the success of national education goals, so far the learning evaluation at all educational level in Indonesia only provides information on academic achievement alone. The present study is expected to provide a valid and reliable learning evaluation instrument related to non-academic important indicators of national education objectives. The current study is a further study aimed at exploring psychometric properties Takwa toward Allah Subahanahu wa Ta'ala Questionnaire (KTA; Fikri \& Kurniawan, 2013). The study involved 220 Islamic boarding school students, comprised $57.3 \%$ male students and $42.7 \%$ female students, and their age ranges 15 years old to 27 years old $(M=17.7, S D=1.90)$. For the purposes of validating the KTA, Surrender to God Scale (SGS; Wong-McDonald \& Gorsuch, 2000), Flourishing Scale (FS; Diener, Wirtz, Tov, Kim-Prieto, Choi, Oishi, \& Biswas-Diener, 2009), Negative Affect Subscale of SPANE (NA Subscale of SPANE; Diener, Wirtz, Tov, Kim-Prieto, Choi, Oishi, \& Biswas-Diener, 2009), and Reynolds Short-Form of Marlowe-Crowne Social Desirability Scale (RSF-MCSDS; Reynolds \& Gerbasi, 1982) were administered to them. The results of the study demonstrated the KTA has satisfying early psychometric evidence as a learning evaluation instrument. The findings, implications, and limits of the study are briefly discussed.
\end{abstract}

Keywords: Takwa toward Allah Ta'ala Questionnaire, Pschometric properties, Islamic boarding school students 


\section{Pendahuluan}

Undang-Undang Dasar Negara Republik Indonesia Tahun 1945 mengamanatkan kepada Pemerintah Republik Indonesia untuk mengusahakan dan menyelenggarakan satu sistem pendidikan nasional yang mampu meningkatkan keimanan dan ketakwaan kepada Tuhan Yang Maha Esa serta akhlak mulia (Undang-Undang Sistem Pendidikan Nasional No 20 Tahun 2003-untuk penulisan selanjutnya disingkat menjadi UU SPN No 20 Tahun 2003). Pendidikan nasional bertujuan untuk berkembangnya potensi peserta didik agar menjadi manusia yang beriman dan bertakwa kepada Tuhan Yang Maha Esa, berakhlak mulia, sehat, berilmu, cakap, kreatif, mandiri, dan menjadi warga negara yang demokratis serta bertanggung jawab (UU SPN No 20 Tahun 2003 Bab II Pasal 3).

Penjelasan di atas menunjukkan bahwa secara yuridis formal evaluasi pembelajaran di semua jenjang pendidikan yang ada di Indonesia seharusnya bukan hanya menyediakan informasi prestasi akademik semata sebagaimana selama ini berlangsung, tapi juga mewajibkan penyelenggara pendidikan untuk menyertakan informasi peserta didik mereka terkait peningkatan Keimanan, Ketakwaan kepada Allah Ta'ala dan Akhlak Mulia. Itu artinya Keimanan, Ketakwaan kepada Allah Ta'ala dan Akhlak Mulia harus menjadi bagian penting sekaligus penentu yang tidak terpisahkan dari system evaluasi pembelajaran di semua jenjang pendidikan, termasuk menjadi indikator capaian pembelajaran di Ujian Nasional.

Takwa kepada Allah Ta'ala merupakan konsep yang sangat penting dalam religiusitas Islam. Sebagai contoh, Allah Ta'ala menyebut ketakwaan sebagai sebaik-baik bekal (QS Al Baqarah (2): 197) dan sebaik-baik pakaian (QS Al A'raf (7):26), sebagai indikator kemuliaan seseorang di sisi Allah (QS Al Hujurat (49): 13), mendapatkan petunjuk dan keberuntungan (QS Al Baqarah (2):5; QS Ali Imrah (3):130; QS Muhammad (47): 17), mendapatkan kemenangan (QS An Naba (78): 31) dan mendapatkan kesudahan yang baik (QS Al A'raf (7): 128); QS Hud (11):49).

Dalam konteks hadis, Rasulullah Muhammad shallallaahu'alaihi wa sallam (AlHilali, 2013) menegaskan ketakwaan sebagai ukuran kemuliaan manusia (HR Bukhari No 387 dan HR Muslim No 2378), sikap terbaik menjalani kehidupan (HR Muslim No 2742), sesuatu yang harus dimohonkan kepada Allah Ta'ala (HR Muslim No 2721), dan menjadi jalan sekaligus syarat masuk surga (HR AtTirmidzi No 616, HR Ahmad No 251, dan HR Al Hakim No 389).

Berdasarkan penjelasan di atas, maka pengembangan instrument evaluasi pembelajaran yang valid, reliabel, dan terstandar secara nasional terkait ukuran-ukuran psikologis Keimanan, Taqwa kepada Allah Ta'ala dan Akhlak Mulia menjadi kebutuhan yang penting dan mendesak untuk dilakukan. Ketersediaan ketiga informasi tersebut memungkinkan pihak-pihak yang berkepentingan pada berbagai level, mulai level individu, keluarga, organisasi/institusi, komunitas, maupun dan pemerintah/negara, mampu melakukan evaluasi pendidikan yang lebih terintegrasi, sehingga perbaikan atas usaha-usaha pendidikan yang sudah dan sedang dilakukan dalam menciptakan sumberdaya manusia Indonesia yang beriman, bertakwa, cerdas, terampil, dan berakhlak mulia menjadi lebih mungkin direalisasikan secara lebih komprehensif.

Takwa, menurut Abdullah Ibnu Mas'ud (Buhairi, 2012) adalah taat dan tidak melakukan maksiat, senantiasa mengingat-Nya dan tidak melupakan-Nya, serta mensyukuri nikmat-Nya dan tidak mengkufurinya. Pendapat yang senada dikemukakan oleh Buhairi (2012) yang menegaskan takwa sebagai sikap menjaga diri dari sesuatu yang ditakuti, yaitu kemurkaan dan hukuman-Nya dengan cara melakukan ketaatan dan meninggalkan kemungkaran. At-Tuwaijiri (2014) menambahkan beriman dan bertawakal kepada Allah sebagai bagian dari definisi takwa selain ketaatan, mengingat, dan bersukur kepada Allah.

Sementara itu definisi yang lebih operasional dikemukakan oleh Ali bin Abi Thalib (Buhairi, 2012) bahwa takwa merupakan perasaan takut kepada Dzat Yang Maha Perkasa, mengerjakan apa yang diperintahkan, puas dengan rezeki yang sedikit, dan mempersiapkan diri untuk menghadapi hari kemudian. Takwa, menurut Buhairi (2012) adalah takut terhadap hukuman Allah, mengagungkan kebesaran Allah, sabar terhadap cobaanNya, ridha terhadap ketetapan-Nya, tunduk 
terhadap kewibawaan-Nya, memikirkan hukuman dan hisab-Nya.

Ali bin Abi Thalib (Buhairi, 2012) menegaskan bahwa Takwa teridiri dari empat unsur, yaitu

1. Takut kepada Dzat Yang Maha Perkasa. Orang yang bertakwa kepada Allah takut kepada Allah Subhanahu wa Ta'ala. Allah Ta'ala memerintahkan orang beriman untuk takut kepada-Nya dan dan melarangnya untuk takut kepada selainNya (QS Ali Imran [3]:175). Takut kepada Dzat Yang Maha Perkasa membuat orang yang beriman merasa diawasi oleh Allah Ta'ala dalam setiap gerak dan diamnnya. Orang yang bertakwa akan lebih berhatihati karena takut akan adzab Tuhan (QS Al Mu'minun [23]:57), takut akan kebesaran Tuhannya, dan lebih mampu menahan diri dari keinginan hawa nafsunya (QS An Naziat [79]:40-41).

2. Mengerjakan apa yang diperintahkan

Orang yang bertakawa kepada Allah mengamalkan perintah-perintah-Nya dan menjauhkan diri dari larangan-laranganNya sebagaimana yang terdapat dalam Al Qur'an. Orang yang bertakwa, menurut Al-Utsaimin (2015) melakukan perintahperintah Allah dan meninggalkan laranganlarangan-Nya karena hal tersebut dapat menghindarkan dirinya dari mendapatkan adzab-Nya.

3. Puas dengan rezeki yang sedikit.

Orang yang bertakwa kepada Allah bersifat qana'ah yaitu merasa puas, cukup dan ridha dengan yang diberikan Allah Ta'ala kepadanya, dan tidak iri terhadap harta yang dimiliki orang lain serta bertawakal kepada Allah Subhanahu wa Ta'ala. Dengan bersikap qona'ah orang yang bertakwa akan merasakan ketenangan jiwa karena terhidarkan dari kerakusan terhadap dunia (harta).

4. Mempersiapkan diri untuk menghadapi hari kemudian

Orang yang bertakwa kepada Allah mempersiapkan diri untuk menghadapi kematian dengan mengerjakan amal saleh seperti shalat, puasa, membaca Al Qur'an dan jihad di jalan Allah.

Fikri dan Kurniawan (2012) mengembangkan Kuesioner Takwa kepada Allah
Ta'ala (KTA) dengan menjadikan 150 siswasiswa SMA di Yogyakarta sebagai sampel penelitiannya. Hasil studi awal tersebut menyediakan bukti psikometrik awal yang potensial dan menjanjikan dari Kuesioner Takwa kepada Allah Ta'ala untuk layak digunakan sebagai bagian instrument evaluasi pembelajaran yang valid, reliabel, dan objektif. Kuesioner Takwa kepada Allah Ta'ala terdiri atas 27 pertanyaan, mengungkapkan empat dimensi yaitu keimanan, akhlak mulia, shalat, dan infaq, mampu menjadi prediktor yang signifikan untuk Religiusitas Islam dan Kepuasan Hidup siswa, dan memiliki koefisien reliabilitas Alpha Cronbach sebesar 0,890.

Studi sekarang ini merupakan validasi lanjutan dari studi Fikri dan Kurniawan (2012). Pertama, mengingat bentuk pendidikan formal di Indonesia yang beragam, termasuk pendidikan berbasis pondok pesantren, maka studi sekarang ini mencoba memperluas cakupan sampel Kuesioner Takwa kepada Allah dengan melibatkan santri pondok pesantres sebagai sampel studi. Ini artinya Kuesioner Takwa kepada Allah Ta'ala dikatakan valid, reliabel, dan terstandar jika mampu menghasilkan informasi psikometrik yang relatif sama/ konsisten meskipun dikenakan pada sampel yang berbeda.

Kedua, berbeda dengan penelitian Fikri dan Kurniawan (2012) yang menjadikan Religiusitas Islam dan Kepuasan Hidup sebagai variabel kriteria validasi, maka penelitian sekarang menggunakan Surrender to God (SGS; Wong-McDonald \& Gorsuch, 2000; SGS-Versi Indonesia, Kurniawan, 2014; 12 aitem dengan $\alpha=0.868$ ), Flourishing (FS; Diener, Wirtz, Tov, Kim-Prieto, Choi, Oishi, \& Biswas-Diener, 2009; FS-Versi Indonesia, Kurniawan, 2014; 8 aitem dengan $\alpha=0.790$ ), dan Negative Affect (NA Subscale of SPANE; Diener, Wirtz, Tov, Kim-Prieto, Choi, Oishi, \& Biswas-Diener, 2009; NA Subscale of SPANE-Versi Indonesia, Kurniawan, 2014; 6 aitem dengan $\alpha=0.827$ ) sebagai variabel kriteria. Untuk menjaga kualitas informasi yang dihasilkan, penelitian sekarang juga melibatkan pengukuran Social Desirability (Reynolds Short Form of MCSDS; Reynolds \& Gerbasi, 1982; Reynolds Short Form of MCSDS-Versi Indonesia, 2012; 11 aitem dengan $\alpha=0.657$ ) sebagai variabel kontrol sebagaimana studi Fikri dan Kurniawan. 
Surrender To God (SGS;Wong-Mc Donald, \& Gorsuch (2000) mengungkapkan tingkat keberserahan seseorang kepada Tuhan yang ditunjukkan dengan enam dimensi pemecahan masalah yaitu, mendefinisikan masalah, mencari alternatif penyelesaian masalah, memilih solusi, menerapkan solusi dari pemecahan masalah, mendefinisikan masalah kembali dan self-maintenance. Flourishing, menurut Diener, Wirtz, Tov, Kim-Prieto, Choi, Oishi, \& Biswas-Diener (2009) merupakan konstrak yang mengungkap evaluasi seseorang terkait pencapaian hidup dengan berfokus pada sisisisi penting dalam kehidupan individu yaitu hubungan sosial, harga diri, tujuan hidup, dan optimism.

Negative affect, menurut Diener, Wirtz, Tov, Kim-Prieto, Choi, Oishi, \& BiswasDiener (2009), konstrak psikologi yang mendemonstrasikan seberapa sering individu mengalami perasaan-perasaan negatif dalam 1 bulan terakhir. Hal ini diungkap dengan cara individu diminta untuk mengingat kembali pengalaman-pengalaman yang dialami selama 1 bulan terakhir, dan memilih kolom intensitas yang menggambarkan seberapa sering subjek mengalami kondisi, perasaan, atau perasaan tersebut. Social desirability (Reynold \& Gerbasi, 1982; Weiner \& Craighead, 2010) merupakan konstrak psikologis yang menunjukkan apakah seorang individu memiliki kecenderungan untuk menyetujui hal-hal yang secara sosial akan menguntungkan dirinya(moralistic bias) dan kecenderungan untuk tidak menyetujui hal-hal yang merugikan dirinya secara sosial (egoistic bias).

Penelitian sekarang ini secara empirik dimaksudkan untuk menggali informasi psikometri sebagai berikut:

1. Bagaimanakah struktur faktor dari Kuesioner Takwa kepada Allah Ta'ala?

2. Bagaimanakah validitas konkuren dan konvergen dari Kuesioner Takwa kepada Allah Ta'ala?

3. Bagaimanakah reliabilitas dari Kuesioner Takwa kepada Allah Ta'ala?

\section{Metode}

\section{Responden Penelitian}

Penelitian yang melibatkan 220 orang santri di Kuningan, Jawa Barat, 57,3\% santri laki-laki dan $42,7 \%$ santri perempuan ini di- lakukan bersamaan dengan studi validasi Kuesioner Tawadhu. Mereka rata-rata berusia 17.77 tahun $(S D=1.90), 44.1 \%$ dari mereka adalah anak pertama dalam keluarganya, dan $28,6 \%$ dari santri menghabiskan uang saku bulanan Rp 150.000,00. Sebanyak 35,5\% dari mereka adalah santri tahfidzh (penghafal Al Qur'an) dan 21,7\% dari mereka hafal 5 juz Al Qur'an.

\section{Metode Pengumpulan Data}

Berbeda dengan studi sebelumnya (Fikri \& Kurniawan, 2013) yang melibatkan pengukuran variabel Religiusitas Islam (PMIR; Raiya, 2008; Baiquni \& Kurniawan, 2012) dan Kepuasan Hidup (SWLS; Diener, Emmons, Larson, \& Griffin, 1985; SWLS-Versi Indonesia, Kurniawan, 2012) sebagai variabel kriteria, studi validasi Kuesioner Taqwa kepada Allah sekarang ini melibatkan pengukuran variabel berikut ini:

Kuesioner Takwa kepada Allah Ta'ala (Fikri \& Kurniawan, 2013). Kuesioner Takwa kepada Allah Ta'ala terdiri atas 27 aitem pertanyaan dengan pilihan respon mulai dari Tidak Pernah (diberi skor 1) sampai Selalu (diberi skor 5). Contoh pertanyaan: "Apakah Anda percaya dengan akal dan qalbu, tanpa paksaan bahwa Allah itu Maha Sempurna dan Maha Suci dari segala kekurangan?" ; "Apakah Anda memilih memaafkan, berbuat baik, dan tetap menyambung silaturahim kepada orang yang telah mendzalimi Anda?". Semakin tinggi skor mengindikasikan semakin tinggi Ketakwaan kepada Allah Ta'ala seseorang dan sebaliknya.

Surrender to God (SGS; Wong-McDonald \& Gorsuch, 2000; SGS-Versi Indonesia, Kurniawan, 2014; 12 aitem dengan $\alpha=0.868)$. Skala Surrender to God terdiri atas 12 aitem pertanyaan dengan pilihan respon mulai dari Tidak Pernah (diberi skor 1) sampai Selalu (diberi skor 5). Contoh pertanyaan: "Ketika pertama kali mencoba memahami sebuah permasalahan, apakah Anda menempatkan (mengutamakan) firman Allah Ta'ala di atas pendapat Anda pribadi?" ; "Apakah Anda memilih untuk tabah karena dan bersama Allah Ta'ala, walaupun itu bisa membuat Anda terkesan/dipandang lemah oleh lingkungan/orang lain?". Semakin tinggi skor mengindikasikan semakin tinggi Surrender to God seseorang dan sebaliknya. 
Flourishing (FS; Diener, Wirtz, Tov, Kim-Prieto, Choi, Oishi, \& Biswas-Diener, 2009; FSVersi Indonesia, Kurniawan, 2014; 8 aitem dengan $\alpha=0.790$ ). Skala Flourishing terdiri atas 8 aitem pertanyaan dengan pilihan respon mulai dari Tidak Pernah (diberi skor 1) sampai Selalu (diberi skor 5). Contoh pertanyaan: "Apakah Anda merasa kehidupan yang dijalani sudah mengarah pada kehidupan yang penuh tujuan dan penuh makna?"; "Apakah Anda merasa orang-orang perduli dan memperlakukan Anda dengan baik/pantas/hormat?". Semakin tinggi skor mengindikasikan semakin tinggi Flourishing seseorang dan sebaliknya.

Negative Affect (NA Subscale of SPANE; Diener, Wirtz, Tov, Kim-Prieto, Choi, Oishi, \& Biswas-Diener, 2009; NA Subscale of SPANE-Versi Indonesia, Kurniawan, 2014; 6 aitem dengan $\alpha=0.827$ ). Skala Negative Affect terdiri atas 6 aitem pertanyaan dengan pilihan respon mulai dari Tidak Pernah (diberi skor 1) sampai Selalu (diberi skor 5). Contoh pertanyaan: "Dalam 1 bulan terakhir ini, apakah Anda cenderung merasa tidak senang dan mengalami kesulitan atau merasa dirugikan?"; "Dalam 1 bulan terakhir ini, apakah Anda cenderung memandang sebuah peristiwa hanya dari sisi yang tidak menyenangkan atau dari sisi kesulitannya?". Semakin tinggi skor mengindikasikan semakin tinggi Negative Affect seseorang dan sebaliknya.

Social Desirability (Reynolds Short Form of MCSDS; Reynolds \& Gerbasi, 1982; Reynolds Short Form of MCSDS-Versi Indonesia, 2012; 11 aitem dengan $\alpha=0.657$ ) sebagai variabel kontrol.

Skala Social Desirability terdiri atas 11 aitem pertanyaan dengan pilihan respon mulai dari Ya dan Tidak., skor bergerak dari 0 sampai 1. Contoh pertanyaan: "Apakah Anda PERNAH merasa kesal ketika tidak mendapatkan sesuatu sebagaimana Anda inginkan?"; "Apakah Anda SELALU menjadi pendengar yang baik dengan siapa pun Anda sedang berbicara?". Semakin tinggi skor mengindikasikan semakin tinggi Social Desirability seseorang dan sebaliknya.

\section{Analisis Data}

Penelitian sekarang ini menggunakan analisis faktor eksploratori untuk mengukur Struktur Faktor dan Validitas Konstrak, analisis korelasi parsial untuk mengungkap validitas konkuren, konvergen, dan diskriminan, serta analisis reliabilitas untuk mengungkap level reliabilitas dari Kuesioner Takwa kepada Allah Ta'ala.

\section{Hasil}

Sebagaimana penelitian sebelumnya (Fikri \& Kurniawan, 2013) yang menggunakan analisis faktor eksploratori dengan metode ekstraksi analisis komponen prinsipal dan metode rotasi varimax, penelitian sekarang juga memakai analisis faktor eksploratori dengan metode ekstrasi dan metode rotasi yang sama untuk menemukan struktur faktor yang menyusun variabel Takwa kepada Allah Ta'ala.

Table 1. Struktur Faktor dan Reliabilitas Kuesioner Takwa kepada Allah Ta'ala

\begin{tabular}{|c|c|}
\hline Properti Psikometri & Informasi \\
\hline \multirow{3}{*}{$\begin{array}{l}\text { Kaiser-Meyer-Olkin Measure } \\
\text { of Sampling Adequacy } \\
\text { Bartlett's Test of Sphericity } \\
\text { (Approx. Chi-Square; df; Sig) } \\
\text { Total varian yang dapat dijelaskan } \\
\text { Jumlah komponen, total initial } \\
\text { eigenvalues untuk masing-masing } \\
\text { komponen }\end{array}$} & 0.862 \\
\hline & $\begin{array}{l}2984.818(351) / 0.000 \\
56.111 \%\end{array}$ \\
\hline & \\
\hline komponen & $\begin{array}{l}\text { 4 Komponen, } \\
\text { - Komponen } 1 \text { (Keimanan): } 7.197 \text { (29.323\% varian) } \\
\text { - Komponen } 2 \text { (Akhlak Mulia): } 4.367 \text { (16.175\% } \\
\text { varian) } \\
\text { - Komponen } 3 \text { (Shalat): } 1.517 \text { (5.619\% varian) } \\
\text { - Komponen } 4 \text { (Infaq): } 1.348 \text { (4.994\% varian) }\end{array}$ \\
\hline Statistik Reliabilitas (Cronbach Alpha/N if item) & $\begin{array}{l}\alpha=0.883 \text { (25 aitem) } \\
\cdot \alpha=0.910 \text { untuk Komponen } 1 \text { (11 aitem) } \\
\cdot \alpha=0.812 \text { untuk Komponent } 2 \text { (7 aitem) } \\
\cdot \alpha=0.812 \text { untuk Komponent } 3 \text { (4 aitem) } \\
\cdot \alpha=0.775 \text { untuk Komponent } 4 \text { (3 aitem) }\end{array}$ \\
\hline
\end{tabular}


KMO Measure of Sampling Adequacy sebesar 0.862 dan Barlett's Test of Spherecity yang signifikan menunjukkan adanya struktur faktor yang mendasari pola-pola korelasi di antara aitem-aitem pertanyaan Kuesioner Takwa kepada Allah Ta'ala dan Takwa kepada Allah Ta'ala terbangun oleh 4 komponen penyusun yaitu Keimanan, Akhlak Mulia, Shalat, dan Infaq. Keempat komponen tersebut secara bersama mampu menjelaskan 56,11\% varians Takwa kepada Allah Ta'ala. Faktor
Keimanan memperlihatkan kemampuan yang paling kuat $(29,32 \%)$ dalam menjelaskan varian Takwa kepada Allah, diikuti oleh Akhlak Mulia $(16,17 \%)$, Shalat $(5,62 \%)$, dan Infaq $(4,99 \%)$ (Tabel 1). Tabel 1 juga memperlihatkan reliabilitas Kuesioner Takwa kepada Allah Ta'ala dan reliabilitas untuk masing-masing komponen Kuesioner Takwa kepada Allah Ta'ala termasuk kategori optimal (lihat Nunnally \& Bernstein, 1994; DeVellis, 2012).

Tabel 2. Matriks Korelasi Antar Komponen Takwa Kepada Allah Ta'ala

\begin{tabular}{lllll}
\hline Komponen & Keimanan & Akhlak Mulia & Sholat & Infaq \\
\hline Keimanan & 1.000 & .314 & .233 & .083 \\
Akhlak Mulia & .314 & 1.000 & .575 & .515 \\
Shalat & .233 & .575 & 1.000 & .437 \\
Infaq & .083 & .515 & .437 & 1.000
\end{tabular}

Extraction Method: Principal Axis Factoring.

Rotation Method: Promax with Kaiser Normalization.

Tabel 2 memperlihatkan korelasi antara empat faktor penyusun Takwa kepada Allah Ta'ala berkisar antara .083 sampai .575, mendukung adanya multidimensionalitas pada skala ketakwaan. Korelasi antar faktor dari rendah sampai moderat menunjukkan bahwa dimensi-dimensi tersebut memiliki korelasi, namun masing-masing dari dimensi tersebut memiliki diferensiasi.

Tabel 3. Validitas Konkuren dan Konvergen, dari Kuesioner Takwa kepada Allah Ta'ala dengan mengendalikan Social Desirability

\begin{tabular}{llll}
\hline Skala Ketakwaan \& Dimensi & Surrender to God & Flourishing & Negative Affect \\
\hline Keimanan & $0.333^{\star *}$ & $0.205^{\star *}$ & -0.096 \\
Akhlak mulia & $0.420^{* *}$ & $0.425^{* *}$ & -0.079 \\
Shalat & $0.359^{\star *}$ & $0.186^{* *}$ & $-0.201^{* *}$ \\
Infaq harta & $0.288^{\star *}$ & $0.269^{* *}$ & 0.030 \\
Ketakwaan & $0.523^{\star *}$ & $0.396^{* *}$ & $-0.125^{\star}$ \\
\hline
\end{tabular}

*. Correlation is significant at the 0.05 level (1-tailed)

**. Correlation is significant at the 0.01 level (1-tailed)

Korelasi yang kuat dan signifikan antara variabel Takwa kepada Allah Ta'ala dan variabel yang sama-sama mengungkap relasi dengan Allah Ta'ala yaitu Surrender to God menunjukkan bukti informasi adanya validitas konvergen dari Kuesioner Takwa kepada Allah Ta'ala. Demikian juga korelasi moderat dan signifikan antara variabel Takwa kepada Allah Ta'ala dan variabel Flourishing-konsep psychological well-being dari Diener dkk (2009)—menambahkan bukti empirik awal dari Kuesioner Takwa kepada Allah Ta'ala.

\section{Pembahasan}

Tujuan pertama studi yang ingin menemukan struktur faktor Kuesioner Takwa kepada Allah Ta'ala mendapatkan dukungan empiric dalam penelitian ini (lihat Tabel 1). Untuk menjawab tujuan penelitian yang 
pertama tersebut, peneliti menggunakan analisis faktor eksploratori karena analisis faktor, menurut Dancey dan Reidy (2011) memungkinkan peneliti menemukan validitas faktorial dari pertanyaan-pertanyaan yang disusun untuk mengungkap sebuah konstrak-dinamakan juga dengan validitas konstrak. Ketika para peneliti mendesain kuesioner, mereka biasanya mengajukan sejumlah pertanyaan yang berhubungan dengan sebuah konstrak: Pertanyaan-pertanyaan tertentu berhubungan satu sama lain karena mereka diasumsikan mengukur konstrak yang sama. Analisis faktor, menurut Howit dan Cramer (2011) mampu mereduksi data yang komplek-berupa aitem-aitem pertanyaan yang banyak-ke dalam jumlah faktor yang lebih sedikit melalui pengujian pola-pola korelasi di antara aitemaitem pertanyaan tersebut dengan faktor baru yang mewadahinya-dinamakan dengan muatan faktor (factor loadings).

Analisis faktor eksploratori, menurut Brace, Kemp, dan Snelgar (2009) tidak untuk menguji hipotesis, tetapi untuk mengeksplorasi kemungkinan adanya sebuah struktur faktor yang mendasari pola-pola korelasi di antara aitem-aitem pertanyaan yang adaTabachnik dan Fidell (2001) menyebutnya sebagai faktorabilitas. Indikator ada tidaknya faktorabilitas dari kuesioner yang dikembangkan, lanjut Brace dkk (2009), dapat dilihat pada informasi-informasi berikut ini:

a. Kaiser-Meyer-Olkin (KMO) Measures of Sampling Adequacy (MSA)

KMO measure of sampling adequacy merupakan sebuah tes terkait jumlah varian dalam data yang dapat dijelaskan oleh faktor-faktor yang ditemukan. Nilai $\mathrm{KMO}$ di sini merupakan nilai rata-rata dari $\mathrm{KMO}$ individual setiap aitem pertanyaan yang ada di kolom anti-image correlation pada output anti-image matrices. Jika ada aitem pertanyaan yang memiliki nilai $\mathrm{KMO}$ $<0.5$, dipertimbangkan untuk dikeluarkan dari analisis.

Kaiser (Field, 2009) merekomendasikan nilai $\mathrm{KMO}$ lebih besar dari 0.5 sebagai batas minimum nilai untuk dapat diterima (barely acceptable-nilai KMO di bawah 0.5 berarti Anda harus menambahkan kembali data Anda atau memasukan aitem baru). Hutcheson dan Sofroniou (Field, 2009) menyebutkan nilai KMO antara 0.5 dan 0.7 sebagai tidak begitu memuaskan, nilai $\mathrm{KMO}$ antara 0.7 dan 0.8 sebagai memuaskan, nilai antara 0.8 dan 0.9 sebagai sangat memuaskan, dan nilai b. KMO di atas 0.9 sebagai sangat memuaskan sekali

Bartlett's Test of Sphericity

Tes Bartlett mengindikasikan adanya faktorabilitas jika nilai signifikansi $(p)$ dari tes Bartlett kurang dari $0.05(p<0.05)$. Sebaliknya, jika nilai $p$ dari tes Bartlett > 0.05 , maka probabilitasnya sangat kecil untuk adanya faktorabilitas dari kuesioner yang dikembangkan.

Nilai KMO-MSA yang sangat memuaskan dan Bartlett's Test of Sphericity yang signifikan (lihat Tabel 1) menunjukkan bukti empiris tentang validitas faktorial-istilah lain dari struktur faktor atau faktorabilitas-dari Kuesioner Takwa kepada Allah Ta'ala. Bukti empiris lain yang mendukung validitas factorial Kuesioner ini adalah adanya korelasi antar komponen Takwa kepada Allah Ta'ala yang terentang dari lemah sampai moderat (lihat Tabel 2).

Hasil studi sekarang ini sejalan dengan studi terdahulu (Fikri \& Kurniawan, 2012) yang sama-sama menemukan struktur faktor ukuran psikologis ketakwaan kepada Allah Ta'ala yang tersusun atas 4 faktor yaitu keimanan terhadap Allah, akhlak mulia, shalat, dan menginfaqkan harta. Temuan penelitian ini sejalan dengan apa yang dikemukakan oleh At-Tuwaijiri (2014) bahwa ketakwaan itu terbangun berdasarkan pondasi yang kuat. Ketakwaan itu memiliki petunjuk-petunjuk dan penguat-penguat yang berasal dari keimanan kepada Allah Ta'ala, Malaikat-malaikat, Kitabkitab, Rasul-rasul-Nya, hari akhir dan amalan shalih yang merupakan hasil dari keimanan, petunjuk, dan cahayanya. Juga melahirkan akhlak terpuji yang merupakan keindahan seseorang. Barangsiapa memiliki sifat sesuai dengan sifat-sfat ini, maka dia termasuk orang yang baik, jujur, dan bertakwa.

Ketakwaan, lanjut Tuwaijiri (2014) adalah bersolek setelah membersihkan diri, berhias setelah menyucikan diri, dengan cara melaksanakan ketaatan setelah meninggalkan kemaksiatan. Berhias diri merupakan amalan yang baik, dan dapat dilakukan dengan hati, anggota tubuh, dan harta. Inti 
dari amalan hati adalah keimanan. Yang dapat mengumpulkan amalan anggota bahdan adalah shalat, yang merupakan tiang agama. Inti amalan dari yang dilakukan dengan harta adalah zakat dan sedekah.

Ketakwaan itu sebenarnya bersumber di dalam hati (QS AI Hajj:32) dan ketakwaan yang dilakukan oleh anggota badan hanyalah efek yang dilahirkan dari ketakwaan dalam hati. Ketakwaan yang dilakukan oleh anggota badan tidak akan memberikan nilai dan timbangan apa pun tanpa ada ketakwaan dalam hati. Setiap nilai Islam yang tidak terbangun berdasarkan hakikat keimanan yang ada dalam hati, tidak akan memberi manfaat sampai disertai keimanan. Hakikat dari keimanan yang ada dalam hati tidak akan bermakna atau memberikan manfaat jika tidak dibarengi dengan aplikasi dari nilai-nilai Islam yang zhahir (At-Tuwaijiri, 2014)

Meskipun hati dipenuhi dengan kecintaan kepada Allah Ta'ala, rasa takut kepadaNya, pengagungan untuk-Nya, menurut AtTuwaijiri (2012), akan tetapi tidak dibarengi dengan bentuk peribadatan secara zhahir, maka yang demikian itu tidak akan menyelamatkan seseorang dari api neraka. Nabi Muhammad Shallallahu 'Alaihi wa Sallam meskipun memiliki ketakwaan dan kehendak sempurna, beliau tetap mau melaksanakan shalat malam sampai kedua kakinya bengkak. Beliau melaksanakan puasa sampai dikatakan bahwa beliau tidak pernah berbuka. Beliau berjihad di jalan Allah, melaksanakan haji dan umrah, mengajak untuk berbuat baik, mencegah dari kemungkaran, berdakwah di jalan Allah, memuliakan tamu, membantu orang-orang yang membutuhkan, bergaul dengan para sahabatnya, melaksanakan semua kewajiban, dan tidak pernah meninggalkan amalan-amalan sunnah, wirid-wirid, dan dzikir

Ketakwaan kepada Allah Azza wa Jalla dapat membaguskan hubungan antara seorang hamba dengan Tuhannya, dan akhlak terpuji dapat membaguskan hubungan hamba dengan hamba-hamba yang lainnya. Nabi Muhammad Shallallahu 'Alaihi wa Sallam memerintahkan kedua-duanya sekaligus, sebagaimana sabdanya, "Bertakwalah kepada Allah di mana saja kamu berada dan ikutilah setiap keburukan dengan kebaikan, niscaya kebaikan itu dapat menghapusnya, serta per- gaulilah manusia dengan akhlak yang baik" (HR Ahmad dan At-Tirmidzi). Ketakwaan kepada Allah Ta'ala akan melahirkan kecintaan Allah kepada hamba tersebut. Dan akhlak yang baik dapat mendorong manusia untuk mencintai orang yang berbuat baik tersebut. Kekurangan yang ada ketika melakukan ketaatan atau pun sesuatu yang buru, dapat dihapuskan dengan perbuatan baik yang dilakukan setelahnya (At-Tuwaijiri, 2014)

Tujuan studi kedua yang ingin mengetahui validitas konvergen dan validitas diskriminan dari Kuesioner Takwa kepada Allah Ta'ala juga mendapatkan dukungan empiris dalam penelitian ini (lihat Tabel 3). Validitas konvergen menurut Azwar (2000) ditunjukkan oleh korelasi yang kuat antara variabel kriteria validasi dan variabel predictor karena keduanya secara teoritis mengukur atribut yang sama. Bukti validitas konvergen Kuesioner Takwa kepada Allah ditunjukkan oleh korelasi antara Takwa kepada Allah Ta'ala dan Surrender to God. Merujuk pada kriteria yang dikemukan oleh Cohen (1988) tentang interpretasi koefisien determinasi (r2), maka Takwa kepada Allah Ta'ala termasuk dalam kategori large effect karena mampu menjelaskan varian Surrender to God lebih dari 25\%, tepatnya sebesar $27,35 \%$. Sementara itu jika dilihat kontribusi masing-masing komponen pembentuk Takwa kepada Allah dalam menjelaskan variable kriteria validasi, maka komponen Akhlak Mulia secara konsisten menempati urutan tertinggi, termasuk kategori medium effect, saat menjelaskan varian Surrender to God $(17,64 \%)$ dan Flourishing $(18,06)$, diikuti komponen Shalat $(12,89 \%)$ dan komponen Keimanan $(11,09 \%)$ ketika sama-sama menjelaskan varians Surrender to God.

Validitas diskriminan menurut Azwar (2000) ditunjukkan oleh korelasi yang negative dan lemah antara variabel kriteria validasi dan variabel predictor karena keduanya secara konseptual teoritis mengukur atribut yang berbeda. Bukti validitas diskriminan Kuesioner Takwa kepada Allah Ta'ala ditunjukkan dengan korelasi negative yang lemah antara Takwa kepada Allah Ta'ala dan negative affect, hanya mampu menjelaskan varian Negative Affect sebesar 1,56\%. Shalat menjadi satu-satunya komponen pembentuk Takwa kepada Allah yang signifikan $(p<0.01)$ dan prediktor yang paling kuat ( $4,04 \%$ ) dibanding- 
kan Takwa kepada Allah Ta'ala (1,56\%) ketika menjelaskan varian Negative Affect. Validitas konkuren dari Kuesioner Takwa kepada Allah Ta'ala ditunjukkan oleh korelasi moderat antara Takwa kepada Allah Ta'ala dan Flourishing.

Tujuan studi ketiga yang ingin mengetahui reliabilitas Kuesioner Takwa kepada Allah Ta'ala mendapatkan dukungan empiric dalam penelitian sekarang ini (lihat Tabel 1). Hasil studi sekarang juga menunjukkan konsistensi hasil ukur yang sama dari Kuesioner Takwa kepada Allah Ta'ala meskipun dikenakan pada sampel yang berbeda. Studi Fikri dan Kurniawan (2013) menemukan koefisien reliabilitas Cronbach $\alpha=0.890$ (27 aitem) dan koefisien reliabilitas Cronbach $\alpha=0.883$ (25 aitem) pada studi yang sekarang. Ini artinya reliabilitas hasil pengukuran Kuesioner Takwa kepada Allah Ta'ala dapat dipercaya karena mendekati apa yang dikemukan oleh Azwar (2000) bahwa pada umumnya reliabilitas hasil pengukuran telah dianggap memuaskan bila koefisien reliabilitas Cronbach $\alpha=0.90$.

\section{Kesimpulan}

Hasil analisis dan pembahasan menyajikan bukti psikometrik awal yang menunjukkan Kuesioner Takwa kepada Allah Ta'ala memiliki kualifikasi yang layak untuk dijadikan instrument evaluasi pembelajaran sehingga menyempurnakan hasil evaluasi pembelajaran yang selama ini sudah berjalan. Diperlukan studi-studi lanjutan di masa yang akan datang dengan melibatkan sampel yang lebih banyak dan beragam, sehingga variabilitas sampel siswa dan jenis layanan pendidikan dapat terakomodasi oleh Kuesioner Takwa kepada Allah Ta'ala. Pada akhirnya instrument ini diharapkan sedikit banyak dapat membantu setiap Muslim untuk mengevaluasi apakah kehidupan yang selama ini dilalui sudah mendekati gambaran kehidupan sebagaimana yang dikehendaki oleh Allah Ta'ala.

\section{Daftar Pustaka}

At-Tuwaijiri, M. I. A. (2014). Ensiklopedia manajemen hati: Fikih ibadah. Jakarta: Darus Sunnah.

Al-Utsaimin, M. (2015). Syarah riyadhus shalihin. Jakarta: Darus Sunnah.

Azwar, S. (2000). Penyusunan skala psikolo- gi. Yogyakarta: Pustaka Pelajar

Baiquni, F dan Kurniawan, I.N. (2013). Pengembangan Psychological Measures Of Islamic Religiousness (PMIR) Versi Indonesia : Studi pendahuluan. Naskah Publikasi. Yogyakarta: Prodi Psikologi, Universitas Islam Indonesia

Brace, N., Kemp, R., \& Snelgar, R. (2009). SPSS for psychologists (4th Ed). London: Palgrave Macmillan

Buhairi, M. A. A. (2012). Tafsir ayat-ayat ya ayyuhal-ladzina aamanu. Jakarta: Pustaka Al-Kautsar

Cohen, J. (1988). Statistical power analysis for the behavioral sciences. Hillsdale, NJ: Lawrence Erlbaum Associates.

Dancey, C.P., \& Reidy, J. (2011). Statistics without Maths for Psychology (5th Ed). London: Pearson Education Limited

DeVillis, R. F. (2012). Scale development (3rd) : Theory and application. London: SAGE Publications Ltd

Diener., E., Wirtz, D., Tov, W., Kim-Prieto, C., Choi. D. Oishi, S., \& BiswasDiener, R. 2009. New measures of well-being: Flourishing and positive and negative feelings. Social Indicators Research. 29. 247-266

Field, A. (2009). Discovering statistics using SPSS. London: SAGE Publications Ltd.

Fikri, D. R., \& Kurniawan, I. N. (2013). Pengembangan ukuran psikologis ketakwaan: Studi preliminer pada siswa SMA. Naskah publikasi. Yogyakarta: Prodi Psikologi, Universitas Islam Indonesia.

Howitt, D., \& Cramer, D. (2011). Introduction to Statistics in Psychology. London: Pearson Education Limited.

Kurniawan, I. N. (2014). Validasi awal pengukuran - pengukuran kesejahteraan psikologis dan koping religius pada sampel orang Indonesia. Yogyakarta: Research Centre for Developing Psychological Measures on Islamic Perspective.

Nunnally, J. C., \& Bernstein, I. H. (1994). Psychometric theory (3rd Ed). New York: McGraw-Hill.

Reynold, W., M. \& Gerbasi, K., C. 1982. 
Development of reliable \& valid Short Form of The MCSDS. Journal of Clinical Psychology, 38, 119-125

Wong-McDonald, A., \& Gorsuch, R. (2000). Surrender to God: An additional coping style? Journal of Psychology and Theology, 28, 149-161.

Weiner, B.I. \& Craighead, W., E. 2010. The Corsini Encyclopedia of Psychology: Fourth edition. New Jersey: John Wiley \& Sons, Inc. 